\title{
The Key Advantages and Disadvantages of Matrix Organizational Structures
}

\author{
Krzysztof Gos*
}

The article is a review of the literature on the key advantages and disadvantages of matrix organizational structures. After providing a brief introduction into the discipline, it identifies and discusses eight major characteristics of matrix organizations. In the reviewed publications, three characteristics are considered primarily as advantages of matrix structures, one as a disadvantage, whereas the four remaining arouse controversies as to their beneficial or negative nature. The controversial characteristics are indicated as a field for further investigation.

Keywords: matrix structures, matrix organizations, matrix management, cross-functional structures.

Submitted: 18.06.2015 | Accepted: 25.10.2015

\section{Kluczowe zalety i ograniczenia macierzowych struktur organizacyjnych}

$W$ artykule zaprezentowano wyniki przegladu literatury dotyczacej kluczowych zalet oraz ograniczeń koncepcji macierzowych struktur organizacyjnych. Po krótkim wprowadzeniu do dziedziny zidentyfikowano w nim i omówiono osiem kluczowych cech organizacji macierzowych. Przeprowadzona analiza publikacji wykazata, że trzy ze wspomnianych cech sa przeważnie postrzegane jako zalety organizacji macierzowych, jedna jako ich ograniczenie, zaś pozostałe cztery budza kontrowersje wśród teoretyków co do ich pozytywnego badź negatywnego charakteru. Owe kontrowersyjne cechy wskazano jako proponowany obszar do dalszych badań.

Słowa kluczowe: struktury macierzowe, organizacje macierzowe, zarządzanie macierzowe, zespoły międzyfunkcyjne.

Nadesłany: 21.07.2015 | Zaakceptowany do druku: 28.09.2015

JEL: M10

\section{Introduction}

One of the key factors determining the success of modern organizations is an accurately selected, properly implemented and effectively managed organizational structure (Galbraith, 2014). This article will discuss the advantages and disadvantages of a specific, multidimensional type of organizational structure, called the matrix struc- ture. It is based on the results of a mixed (statistical and bibliographic) literature review and placed in the context of organizational management. Importantly, the terms "matrix structure", "matrix organization" and "matrix management" tend to be treated as interchangeable in the literature. A matrix is broadly "any organization that employs a multiple command system that includes not only a multiple command

\footnotetext{
* Krzysztof Goś - Faculty of Management, University of Warsaw.

Adres do korespondencji: Faculty of Management, University of Warsaw, ul. Szturmowa 1/3, 02-678 Warszawa; e-mail: gos.krzysztof@gmail.com.
} 
structure but also related support mechanisms and an associated organizational culture and behavior pattern" (Davis and Lawrence, 1977, p. 3). Such organizations are therefore built based on two or more "overlaid" dimensions. Individuals from various functional departments work together with the aim to achieve a single, common project goal. They report both to the project leader and their direct functional superiors (Youker, 1977). In consequence, many authors indicate that matrix management poses much more challenges in operation than a traditional hierarchical structure (Atkinson, 2003; Bartlett and Ghoshal, 1990; Galbraith, 2013; Kisielnicki, 2014; Numerof and Abrams, 2002; Prahalad, 1976; Whitford, 2006).

Figure 1. Reporting schemes in a traditional hierarchy and a basic matrix structure

Traditional hierarchical structure

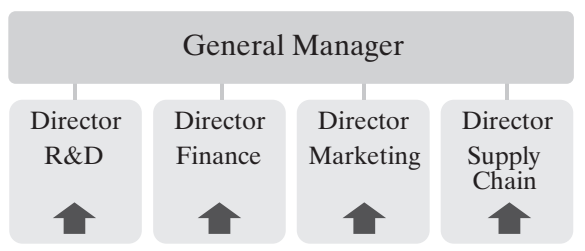

Matrix structure: functional / project

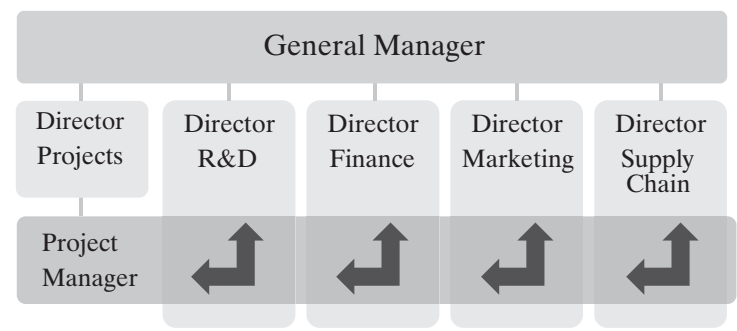

Source: Own compilation based on (Whitford, 2006; Youker, 1977).

The academic interest in matrix management originates from the mid-1900s, when it had its roots in large-scale projects of the U.S. government, such as the Manhattan project, ballistic missile programs or the Apollo aerospace endeavors (Cleland, 1981b; Mee, 1964). The success of the aforementioned projects encouraged a large number of innovative companies from other industries to quickly implement a matrix structure (Anderson 1994; Duliniec, 2009; Galbraith 1973, 2008; Goggin 1974; Hill, 1974; Perham, 1970; Zdziarski, 2014). Many of those early implementations proved to be unsuccessful. One of the key problems in implementing matrix structures in industries outside the aerospace field was about them becoming "heavy" bureaucracies with increased headcount and multiplied processes (Anderson 1994; Gottlieb 2007). The main advantages of the new structure, flexibility and efficiency, became its actual backsides. Additionally, this caused a lot of conflicts among matrix members from different departments, as they were neither used to operating in this kind of environment nor trained in this respect. The matrix was forced on organizations instead of evolving from a true need. Due to the spectacular failures, as Gottlieb put it, "by the mid-1980s, it was hard to find anyone to defend matrix management" (Gottlieb, 2007, p. 8). The literature on matrix management until the late 1980s and 1990s is pretty much elusive compared to the 1960s and 1970s. It is also mostly critical towards the approach, which resulted in a wealth of knowledge on its disadvantages (Ford and Randolph, 1992). Looking back at this period, one might wonder whether the matrix structures were ever really abandoned. Some authors suggest they just changed their name (Anderson, 1994). In the mid-1980s and 1990s, the concepts of "teams" and "project management" captured the imagination of theorists and practitioners (Gottlieb, 2007). In fact, these structures could often be defined as matrix organizations, but were just called differently. The project manager leading a cross-functional team is the very same key person in a matrix organization. In the $2000 \mathrm{~s}$, a resurgence of matrix culture could be recognized (Galbraith, 2013). It remains being perceived as modern, yet there is higher awareness of the combined challenges (Kisielnicki, 2014). Many matrix elements are re-emerging and taking the central place in many present organizations. Some suppose "there is something inherently correct in the matrix structure that continually reasserts itself" (Gottlieb, 2007, p. 11). Given their recent re-emergence, it appears justified to take a fresh look at the key characteristics of matrix structures.

\section{Key characteristics of matrix structures}

The literature review conducted for the purpose of this article had the form of a statistical literature analysis, followed by a traditional bibliographic screening. 
Firstly, 24 most relevant and cited journals were identified based on the SJR Index. Secondly, 4500+ publications were reviewed, out of which approximately 70 were included in this article. Those sources were then complemented by around 30 more, identified in the bibliographic review.

The publications on matrix structures are full of lists, tables, graphs and case studies about their advantages and disadvantages (Appelbaum, Nadeau and Cyr, 2008; Cleland, 1981a; Lawson, 1986; Numerof and Abrams, 2002; Sy and D'Annunzio, 2005; Whitford, 2006; Wright, 1980). Importantly, although only a few of those sources are actually empirically based, they have become commonly accepted by the academics over time. This is likely because the existing empirical evidence is, in most cases, qualitative and limited in terms of sample scope. At the same time, surprisingly few companies track and analyze the performance of their matrix structures (Sy and D'Annunzio, 2005). To address this need, it is crucial to understand what should be tracked as their potential strong or weak points.

One of the key features of matrix organizations is the "overlay" between the functional and project structures, which is coupled with the creation of temporary teams of experts from various departments. It also appears to be the root aspect for both benefits and flaws of matrix structures. Most of matrix advantages are linked with the increased efficiency of horizontal communication, while disadvantages are often derived from the creation of dual (or multiple) lines of reporting and influence (Ford and Randolph, 1992). In other words, "the challenges of matrix-like organizations are primarily related to the fact that two different interdependencies and considerations are built into the structure and not what these dimensions are" (Nesheim, 2011, p. 112).

At the same time, it very often happens that one characteristic of matrix structures is described as positive by one author and as negative by the other. Analyzing the publications referring to problems and costs linked with running a matrix organization, one might find out that "many of them are not so much complementary to the advantages we have listed, but contradictory - the same factors, but with the sign reversed" (Knight, 1976, p. 122). The literature on matrix organizations is in fact full of such paradoxes (Ford and Randolph, 1992; Turner, Utley and Westbrook, 1998).

To properly address the indicated unique situation, this review is constructed in a different way than for a standard structure type. Rather than indicating separately the advantages and disadvantages, it proceeds along the key characteristics, for each one discussing both sides of the coin. Within the conducted literature analysis, eight such characteristics were distinguished, as presented in Table 1 . The analysis revealed that three of them are usually perceived as advantages of matrix organizations: (1) Managing complexity, (2) Communication effectiveness, (3) Output quality. Four arouse the aforementioned controversies among authors: (4) Cost effectiveness, (5) Motivation and job satisfaction, (6) Decision-making effectiveness, (7) Balance of power. One was predominantly presented as a disadvantage: (8) Level of conflicts. All of the eight characteristics listed above will be discussed in more detail.

\section{Managing complexity}

Although almost four decades after being published, a statement by Knight still seems valid: "The [...] comparative organizational studies have left us with rather a limited, and highly generalized, stock of research-based knowledge. The main conclusion to emerge from this body of research (and even this is still controversial) is that 'organic' organizations, which emphasize lateral communications, individual discretion, and participative decision-making, are more appropriate to situations of uncertainty and rapid change, than more strongly hierarchical ones in which the emphasis is on vertical communications, prescribed rules and authority, while the latter are more effective in stable, predictable situations" (Knight, 1976, p. 121). Many managers realized that neither building huge and complex organizations nor oversimplifying them is a good response to the increasing complexity of the environment. They accepted the need to flexibly manage complexity instead of trying to match or minimize it (Bartlett and Ghosal, 1990; Schermerhorn, 2008; Zdziarski, 2014). This ability, combined with the increasingly turbulent and developing conditions, is often indicated as a key source 


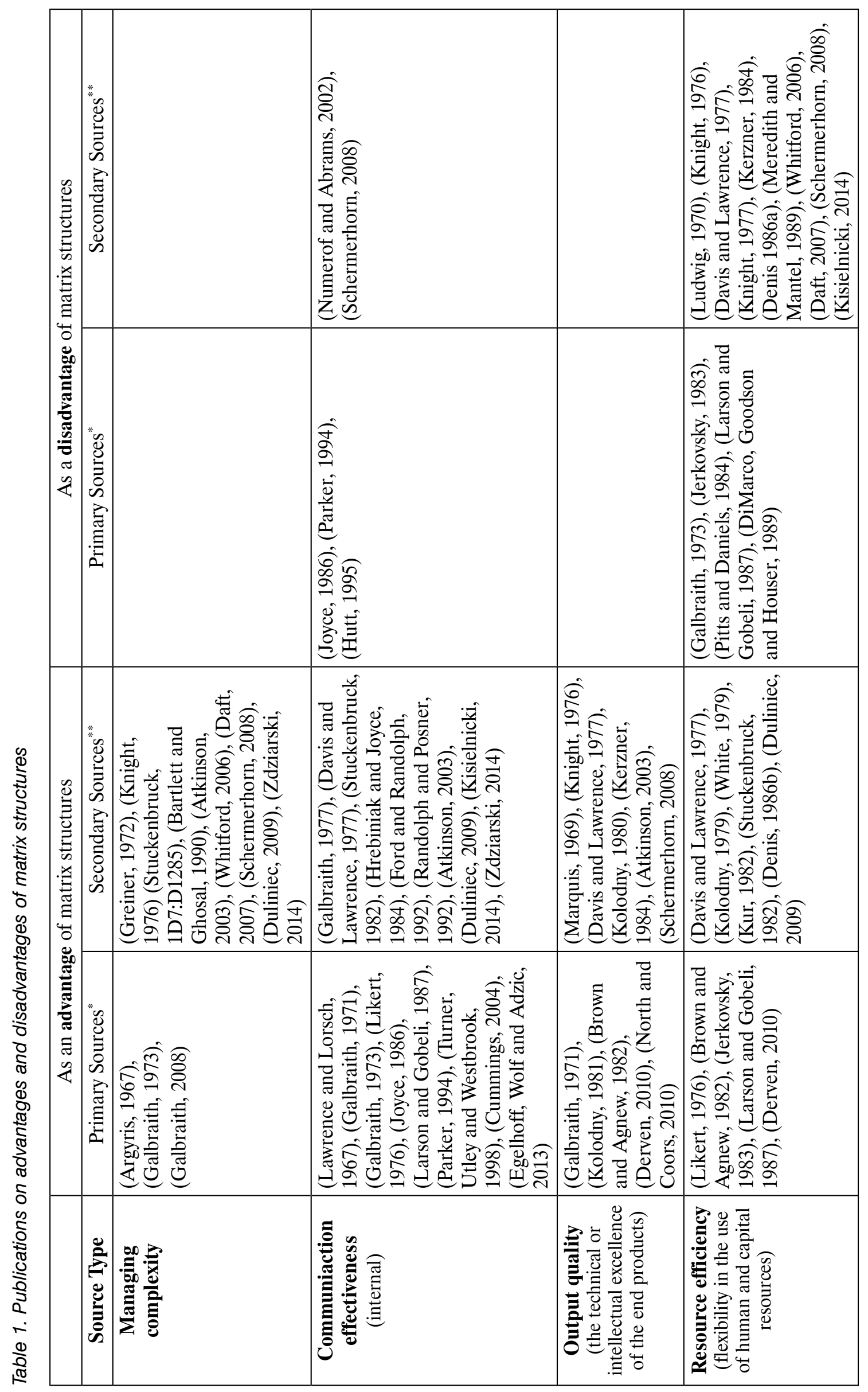




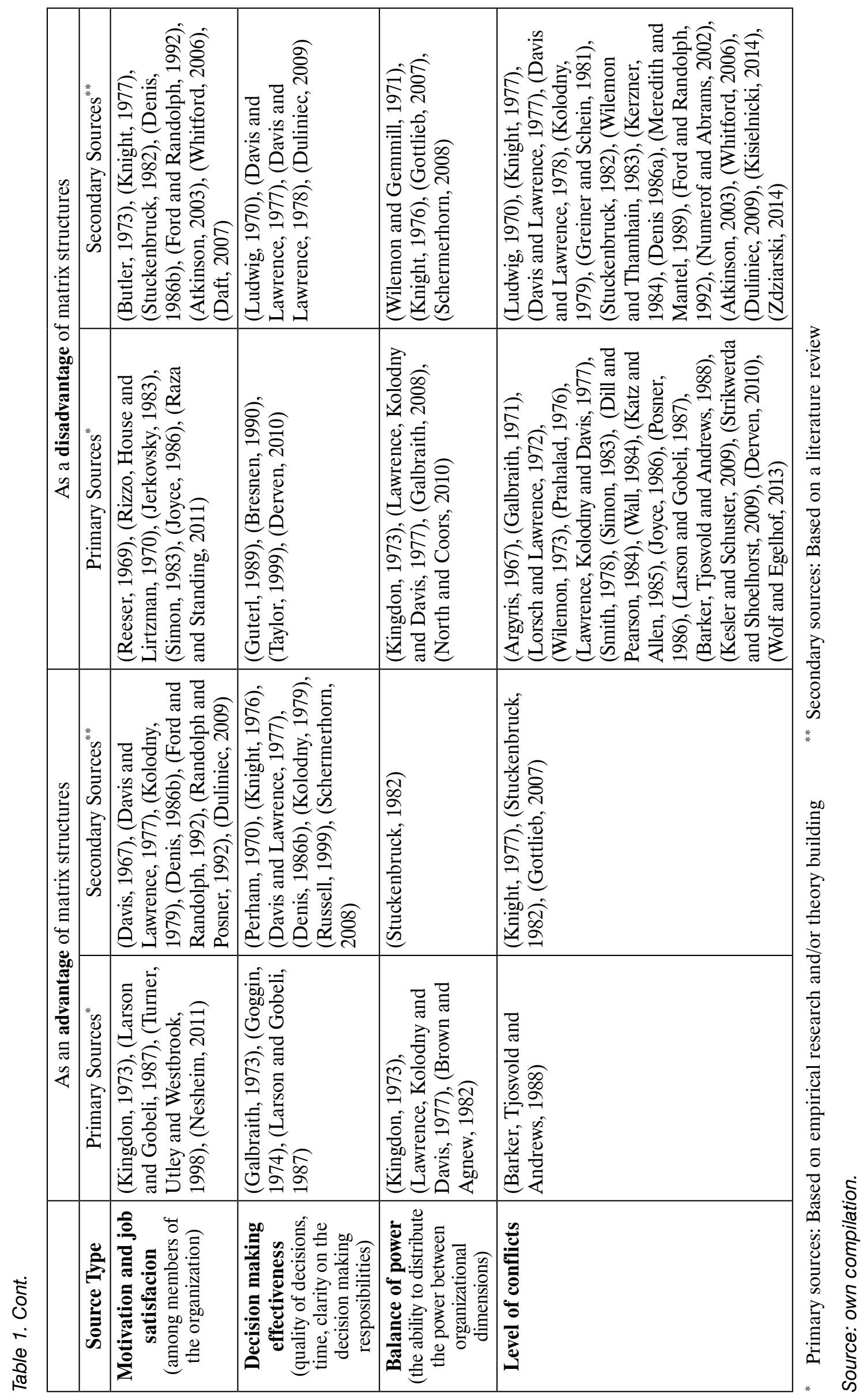


for the emergence of matrix structures. It is all about the transition from a rigid, bureaucratic, hierarchic system to a more flexible form, based on direct contact and communication. The specific explanations assume different perspectives, though. Authors point out that the matrix organization and the use of cross-functional teams is one of the responses to increasingly competitive environment and the development of modern tools for administration and information management to deal with complexity (Andrew, 1983; Argyris, 1967; Duliniec, 2009). Stuckenbruck interprets it as far as to say that they "evolved to meet the needs of our increasingly complex society" (Stuckenbruck, 1982). Greiner associates the shift to matrix management more with increasing internal complexity, but driven by the growth of organizations in terms of size. In this view, the matrix replaces the formal bureaucratic structure with a more flexible structure based on horizontal communication and exchange (Greiner, 1972). This issue becomes especially relevant in global businesses with both global and local units, which automatically defines a matrix situation (Naylor, 1985). In combination with this, the matrix allows to release the complexity-driven pressure to share resources across products or geographies (Daft, 2007; Whitford, 2006). Another perspective includes the complex and volatile world of network and virtual businesses as a field in which matrix structures excel (Atkinson, 2003).

With all that in mind, most authors agree that managing complexity is a key benefit of matrix structures. On the one hand, it increases the information-processing ability of the organization and, on the other, makes it easier to alter its operations in response to volatility of the environment (Galbraith, 2008).

Matrix organizations can respond to complexity in several ways, depending on its origin, as it can be either internal (size, technology) or external (markets, competitors, collaboration with other organizations) (Galbraith, 1973). In any case, it usually means that the organization has increased amounts of information to process and at some point is not able to effectively process it. Galbraith identifies four possible responses: (1) Creation of slack resources, (2) Creation of self-contained tasks, (3) Investment in vertical informa- tion systems, (4) Creation of networks of lateral relations (Galbraith, 1973). According to this analysis, matrix structures deal with the communication and decision needs that arise in complex cross-functional initiatives, "subject to critical time and cost constraints, which by definition, have neither the option of slack resources, nor that of self-contained tasks" (Knight, 1976, p. 116).

As managing complexity is one of the core benefits of a matrix structure, it should be no surprise that during the conducted literature review no significant sources were identified to classify it as a disadvantage.

\section{Communication effectiveness}

In the eyes of many authors, a key advantage of matrix structures is that they solve the information-processing problem often present in traditional hierarchies (Davis and Lawrence, 1977; Egelhoff et al., 2013; Galbraith, 1971, 1973, 2008; Hrebiniak and Joyce, 1984; Zdziarski, 2014). The main contributor to this effect is the increased effectiveness of internal communication. A matrix setup generates more formal and informal lateral communication channels which are not available in the traditional bureaucratic organization (Duliniec, 2009; Ford and Randolph, 1992). Often, it legitimizes such channels, which existed informally before, driven by the need. This happens especially often in modern network and virtual organizations (Atkinson, 2003). At the same time, implementing a matrix structure reduces the need for vertical communication by creating more independent project teams focused on one common and specific task. It improves communication among different departments and project teams by forcing their members to maintain close contact with their cross-functional organizational partners, as this is key to their project's success (Ford and Randolph, 1992). In many instances, communication channels become shorter (Kisielnicki, 2014). Although most evidence in this field is qualitative, some authors managed to document the positive impact of matrix structures on communication also quantitatively (Cummings, 2004).

Joyce argued that three hypotheses should be considered with regard to communication when implementing a matrix: 
(1) Amount and frequency of formal communication should increase, (2) Informal communication should decrease, (3) Directive quality of formal communication should increase (Joyce, 1986). The study conducted by Joyce proved that the first two hypotheses seemed highly probable, the last one was not always relevant. Instead of the predicted increase in the quality of formal communication, the researched sample displayed a decrease. According to Joyce, this might have been driven by the lack of a supporting culture in the study group. Other authors also underline that the quality of horizontal communication in a matrix depends on open and problem-solving oriented climate (Davis and Lawrence, 1987; Galbraith, 1973, 1977; Stuckenbruck, 1982). Sometimes, this even requires an integrator, a person who mediates among the departments in the matrix setup (Lawrence and Lorsch, 1967). All this automatically means that communication and people skills gain more prominence in a matrix organization, which is also combined with the politics around the "battle" for resources and priority in a matrix organization (Galbraith, 1971; Joyce, 1986; Larson and Gobeli, 1987; Randolph and Posner, 1992). Parker indicates the main fields of competence in that aspect: (1) Team leadership, (2) Goal alignment, (3) Tactics of fostering internal communication, (4) "Building bridges" to stakeholders outside the team (Parker, 1994). Communication in a matrix organization can be also enhanced by the use of e-mail, bulletin boards and more frequent face-to-face meetings (Turner et al., 1998).

Although many authors agree that a properly implemented matrix structure should increase the information-processing capability of an organization, there are voices to the contrary. Most of the critics point to the fact that the matrix does increase the quantity of horizontally exchanged information, but reduces its quality (Joyce, 1986; Numerof and Abrams, 2002). This may be driven by the amount of necessary information, but also by forcing horizontal dependencies among departments which normally would have more limited access to one another. Very often, they simply use a different language. Functional units often develop a specialized language, which reflects how their members gather, interpret understand and respond to information (Zenger and Lawrence, 1989). It makes communication more effective within the unit, but also more difficult at a cross-functional level in a structure such as a matrix. People from one department, unfamiliar with the coding, are likely to misinterpret or distort the information from other units (Hutt, 1995). Also from a manager's perspective, a matrix, while addressing external and internal complexity drivers, often becomes complex itself and makes it difficult for managers to communicate clearly among the large number of groups they are connected with (Numerof and Abrams, 2002; Parker, 1994). This also sometimes causes confusion among employees, who receive doubled or even contradictory commands from the two managers they report to (Schermerhorn, 2008).

\section{Output quality}

An advantage of the matrix, resulting from its other strengths, is the quality of organizational outputs, perceived through the technical excellence of final products (Brown and Agnew, 1982; Davis and Lawrence, 1977; Derven, 2010; Galbraith, 1971; Schermerhorn, 2008). These products might have a material form, but also be any kind of service. Knight argues that this is because matrix structures "[...] facilitate high quality and innovative solutions to complex technical problems" (Knight, 1976, p. 119). According to North and Coors, "when organizations succeed with matrix structures, significant positive outcomes usually result from employees sharing ideas and resources" (North and Coors, 2010). More specifically, while the presence of project teams increases the probability of meeting cost and time objectives, the successful use of functional expertise can be associated with higher technical excellence of the end products (Marquis, 1969). All this indeed seems to be connected with the other discussed advantages, such as improved communication, complexity management or effective resource allocation. Improved information-processing capabilities foster the exchange of best practices and ideas among departments. The increased sharing of technical information among functional experts allows more optimized improvement to the end product. Improved communication also requires the 
technical staff to become more "customer facing" by connecting them with other departments, such as consumer research or marketing (Atkinson, 2003; Schermerhorn, 2008). More flexibility in response to the complex and changing environment allows the organization to make rapid decisions and adjust them when relevant (Kerzner, 1984). Efficient resource allocation allows for assigning the key talents and financial resources in a way which optimizes the end result. It is also hard to overestimate the importance of matrix structures in enabling the development of knowledgeable, technically proficient and flexible individuals. In summary, the excellence of end products in a matrix benefits from exchange of functional expertise, while remaining flexible and innovative (Davis and Lawrence, 1977; Kolodny, 1980, 1981; North and Coors, 2010).

\section{Resource efficiency}

Resource efficiency of matrix structures is one of the characteristics which arouse much controversy. There are strong groups of authors who consider it as either an advantage or a disadvantage of matrix structures. It is important to mention at this point that solid empirical data is very limited for both groups (Ford and Randolph, 1992).

Derven states that "[...] in many organizations, a matrix structure is implemented to address the requirement to do more with less and become more agile" (Derven, 2010, p. 42) Numerous publications support this perception, arguing that thanks to the improved communication, the expert personnel, equipment and budgets are more efficiently allocated as compared to a traditional organization (Brown and Agnew, 1982; Likert, 1976). The available publications indicate two main groups of positive aspects in terms of matrix structure cost efficiency: (1) Related to better information flow, (2) Related to intensive boundary transactions. Firstly, improved communication and a variety of perspectives among project team members in a matrix allow the resources to be quickly and accurately redistributed from unproductive uses to identified, more productive opportunities (Davis and Lawrence, 1977; Derven, 2010; Jerkovsky, 1983; Kolodny, 1979; Kur, 1982; Larson and Gobeli, 1987;
Likert, 1976; Stuckenbruck, 1982). Also at a more general level, closer cooperation, visibility and doubled superiorities among senior managers lead to more open discussions on resource allocation. Matrix management dismantles the habit among the departmental leaders to look at and optimize only their own resources (Likert, 1976). This often leads to managers pitching for resources at the senior leadership, as they believe one initiative offers a better return on investment than another. Such negotiations ultimately result in a more optimal allocation of specialists, equipment and budget among the projects (Denis, 1986b; Duliniec, 2009; White, 1979). One functional expert can be assigned to more than one initiative, having many project bosses and one functional manager. His technical expertise is preserved from being lost or diluted, as he remains closely connected with his parent department (Denis, 1986b; Jerkovsky, 1983). Secondly, a matrix organization is more open and closer to the external environment. As a result, in some matrix forms the project managers have the right to sub-contract services outside the organization that can be supplied internally, but also functional teams have the corresponding right to sell their services to external clients (Kolodny, 1979). In this way, the internal inter-departamental "prices" are market-driven, each team is forced to be competitive and organizational waste of resources is minimized.

The opponents of the above indicated statements argue that "efficiency-based arguments for the organizational shift from product-line to matrix structures are actually suspect" (Whitford, 2006, p. 450) They indicate that matrix management also means: (1) Increased headcount, (2) Organizational heaviness, (3) Additional training costs, (4) Incremental support systems costs (Davis and Lawrence, 1977; Denis, 1986a; Whitford, 2006). Firstly, the presence of dual reporting lines might generate additional headcount, both in terms of management overhead and administrative staff (Davis and Lawrence, 1977; Kerzner, 1984; Larson and Gobeli, 1987; Schermerhorn, 2008). If the concept of double reporting is interpreted too directly, a matrix indeed might actually double the number of senior managers. In many organizations though, this effect is being reduced by "double-hatted" positions. Secondly, a matrix organi- 
zation requires people to spend far more time on meetings, discussions rather than doing their core work, as compared to a traditional functional structure. There is simply a higher need for communication to be addressed, more information has to reach more people either through a digital, written or personal channel (Knight, 1976). This results in organizational "heaviness" and increased information-processing costs (Davis and Lawrence, 1977; Denis, 1986a; Jerkovsky, 1983; Pitts and Daniels, 1984). Thirdly, matrix structures require incremental training for employees from all involved functions in order to be implemented and function successfully. Importantly, this is not a one-off cost, as training in a matrix ought to be a continuous process (Daft, 2007; DiMarco, Goodson and Houser, 1989; Ludwig, 1970; Whitford, 2006). Lastly, implementing a matrix structure incurs the costs of support systems associated with monitoring, controlling and coordinating people, projects and other systems within the matrix (Jerkovsky, 1983; Kerzner, 1984; Kisielnicki, 2014; Knight, 1977; Larson and Gobeli, 1987).

Although some critics go even as far as to state that the costs of underused human and physical resources are also likely to increase in a matrix, some of them admit that their remarks might apply more to the short term. In the long run, a successful matrix organization is a response to a problem of information processing, and might actually reduce costs (Davis and Lawrence, 1977; Galbraith, 1973; Meredith and Mantel, 1989). When additional information processing is required, the costs of this activity simply have to be paid in one way or another. From this perspective, a matrix organization may come up as a cheaper alternative when compared to the costs of large, fully fledged management information systems or alternative costs of time over-runs (Knight, 1976).

\section{Motivation and job satisfaction}

The impact on the level of motivation and satisfaction among employees is another controversial aspect of matrix organizations, with significant groups of authors seeing it as either their strong or weak point.

Some of the authors suggest that implementing a matrix structure should overall have a positive influence on motivation, job satisfaction, commitment, and personal development (Denis, 1986b; Larson and Gobeli, 1987; Nesheim, 2011; Randolph and Posner, 1992; Turner et al., 1998). Their publications usually refer to one of two key sources of increased motivation of individuals: (1) Increased development opportunities, (2) More empowerment. Firstly, a matrix organization offers opportunities to work closely on a wide variety of projects with individuals from many various backgrounds and parts of the organization. This in itself presents an opportunity to learn and develop faster than in a hierarchic structure. The employees in a matrix exchange ideas, information, experiences and perspectives more intensely. Working in a matrix simply gives a broader perspective and more opportunities to learn (Nesheim, 2011). Individuals benefit in terms of development of their interpersonal skills, problem solving abilities and project management (Davis and Lawrence, 1977; Ford and Randolph, 1992; Kolodny, 1979). In a matrix, there is also a broader spectrum of possible career paths for each individual, created by two trajectories functional and managerial (Kolodny, 1979). A matrix organization simply needs strong employees in order to function effectively. For that reason, it is likely that it trains them properly and assists to develop into knowledgeable, broadly skilled, technically competent and matrix-comfortable individuals (Duliniec, 2009; Ford and Randolph, 1992). On top of that, functional employees in a matrix unlearn reactive behaviors, being forced to anticipate upfront the needs of functional and project managers (Kolodny, 1979). Secondly, a matrix organization is much more democratic in the way decisions are made. It is much closer to the social norms employees of large organizations are used to, which leads to their improved motivation (Davis, 1967). Not to be underestimated is the simple satisfaction coming from the higher involvement of employees in decision-making (Randolph and Posner, 1992).

Hard evidence for beneficial impact of a matrix on motivation and job satisfaction is scarce as usually in the discussed field, and consists mainly of case studies. One of the most famous ones was the "motivation batcave" (Kingdon, 1973). In this extreme example of high motivation in a matrix, 
a group of engineers and programmers facing a tight deadline volunteered to work together in a single large office, non-stop, with two shifts, until the issue was solved and the software and hardware were working smoothly (Kingdon, 1973). In their case study analysis, Turner, Utley and Westbrook point out that the impact of a matrix on motivation may differ between the functional and project managers (Turner et al., 1998). The proportion of functional managers who were satisfied with their job was lower than in the case of project managers. This was driven by a large number of negative hygiene factors experienced by the functional managers, as described by Herzberg's Two Factor Theory of Hygienes and Motivators (Herzberg, Mausner and Snyderman, 1959).

More quantitative sources include the work by Denis, which confirmed that a matrix drives stronger team work, higher participation in decision-making, increased autonomy and more development opportunities compared to traditional hierarchies. It also allows a higher degree of own initiative and creativity. All this resulted in higher motivation and job satisfaction scores among the surveyed engineers in a matrix organization (Denis, 1986b). Another piece of strong evidence comes from Nesheim, who conducted a survey in 2009 among managers in a matrix, which confirmed that a matrix strongly facilitates competence development and therefore increases motivation (Nesheim, 2011).

Many publications offer a contrary view, presenting matrix organizations as workplaces that are very stressful and full of conflicts, which has a negative impact on individual motivation and job satisfaction (Atkinson, 2003; Butler, 1973; Joyce, 1986; Reeser, 1969; Rizzo, House and Lirtzman, 1970; Simon, 1983; Whitford, 2006). They underline the difference between purposeful and dysfunctional conflicts, indicating that the latter dominate in matrix structures (Knight, 1977). Also, the changing, ambiguous distribution of authority leads to ambiguity of individual roles, conflicts and stress for the functional and project managers, but also the line staff (Atkinson, 2003; Jerkovsky, 1983; Stuckenbruck, 1982). The mentioned authors point out that the negative impact of additional stress on motivation in a matrix overpowers the aforementioned positive factors. There is a trade-off between the higher empowerment of individuals and the level of stress they need to cope with (Ford and Randolph, 1992). Some authors underline that increased conflict resolution skills are required to navigate in such an environment (Daft, 2007; Whitford, 2006). In fact, the critics seem to have a response to every positive motivational aspect of a matrix. They emphasize that the stress generated in a matrix has a destructive impact on employee motivation and engagement because of: (1) Turf Battles, (2) Confusion around responsibilities, (3) Unclear reward and career development, (4) Temporary character of a matrix, (5) Role overload (Joyce, 1986; Simon, 1983). The first point refers mostly to managers competing constantly for the resources and power, often also having misaligned objectives. This automatically generates dysfunctional conflicts, stress and frustration, often also cascaded on the line staff (Atkinson, 2003). The second point refers to unclarity around the responsibility of individuals who report to more than one manager. In multiple reporting systems, the managers often have contradictory goals themselves, which results in each one of them pulling their reporting individuals in a different direction. Unsurprisingly, such a situation is very stressful for the employee. Individuals are also expected to take more personal initiative (how much?) in defining their roles, resolving conflicts (what methods?) and making personal decisions. The ambiguous structure of authority in a matrix has a negative impact on motivation and satisfaction (Ford and Randolph, 1992). Moreover, the lateral and hierarchical authority structures might be inconsistent, causing the so called "intersender role conflict" (Joyce, 1986; Rizzo et al., 1970). The third point is also rooted in the violation of the oneboss principle. Many problems concerning the reward systems arise when structures with multiple reporting still reward people for behaving in a functional, hierarchical manner (Atkinson, 2003). Career development and appraisal are also possibly difficult to manage in a matrix. Individuals who report to multiple managers and cooperate horizontally with many departments should always be assessed from many angles. Often this either does not fully happen or means additional stretch for their managers (Atkinson, 2003). The fourth point refers to the fact that the conflict might be rooted 
in the change which is inscribed into matrix management (Joyce, 1986; Raza and Standing, 2011). Projects are started and come to a close, responsibilities are often shifted as the initiatives progress. A recurring process of change is inherent in matrix organizations, often resulting in the feeling instability and unclarity among their employees. Lastly, individuals in matrix structures suffer from role overload. The additional workload coming from multiple supervision, combined with increased demand for horizontal communication, often creates conflicts among multiple role expectations and generates stress for individuals not able to satisfy them all (Joyce, 1986; Rizzo et al., 1970). The increased workload is rarely followed by a proportional growth in headcount.

Although these negative factors are hard to quantify and their effects on the organization are even harder to be assessed, authors generally agree that individuals pay a certain price in the "stress" currency for working in a matrix. Obviously, the better a matrix is managed, the lower is the intensity of the negative factors, the higher is the impact of the positive ones and therefore the higher is the productivity of the whole organization (Denis, 1986b).

\section{Decision-making effectiveness}

The effectiveness of decision-making, perceived through the lens of accuracy and time, is also a topic surrounded by disagreement among the authors.

The logic presented by the supporters of matrix management in terms of decisionmaking is rather straightforward. It is based on the following assumptions: (1) Better information flow, (2) Operational decisions made at a lower level, (3) Freed-up senior management. Firstly, the increased horizontal communication among departments allows better information flow, which might effectively foster quicker and more informed decisions (Davis and Lawrence, 1977; Denis, 1986b; Galbraith, 1973; Kolodny, 1979; Larson and Gobeli, 1987; Perham, 1970; Russell, 1999; Schermerhorn, 2008). Presently, staying ahead of the competitors requires from organizations a high level of flexibility and ingenuity also in terms of the speed of decision-making. Secondly, in a matrix the time to market in innovation projects can be reduced through more rapid and accurate decision-making, because operational decisions are made at lower levels of the organization, where the actual operational knowledge is positioned (Russel, 1999). Thirdly, an important point made by Goggin underlines that a matrix, with its more democratic, "downward-distributed" authority structure, frees top management from the need to be involved in day-to-day operations through the delegation of ongoing decision-making. This allows senior managers to spend more time and focus on the strategic decisions (Goggin, 1974; Knight, 1976; Schermerhorn, 2008). Additionally, it improves job satisfaction of empowered employees (Jaremczuk, 2013).

From the opposite perspective, three key sources of negative impact on decisionmaking most often mentioned in the literature are: (1) Internal competitiveness and turf battles, (2) Blurred responsibility, (3) Tendencies for anarchy, (4) Increased bureaucracy (Derven, 2010; Guterl, 1989). Firstly, contradictory objectives in large matrix organizations often lead to lengthy and unproductive discussions which tend to become a part of the aforementioned turf wars - confrontations among managers competing for authority and resources. In such cases, decisions in a matrix are often slow and suboptimal (Derven, 2010; Guterl, 1989; Ludwig, 1970). Secondly, additional horizontal connections of a matrix increase also the number of units involved in the decision-making process and therefore might inhibit it (Bresnen, 1990; Duliniec, 2009). It also often happens that a matrix is wrongly understood as equal to group decision-making. Project and functional managers do not decide unilaterally; therefore, the responsibility becomes somewhat blurred. This requires them to "[...] use their knowledge, competence, relationships, force of personality and skills in group management to get people to do what is still necessary for project success" (Davis and Lawrence, 1977, p. 87). Taylor suggests that otherwise decisions simply might not be made because of the matrix structure (Taylor, 1999). Thirdly, Davis and Lawrence go even as far as to say that matrix organizations, because of the blurred responsibility, have tendencies toward anarchy, "a formless state of confusion where people do not recognize a boss to whom they feel responsible" (Davis and Lawrence, 1978, p. 132). Lastly, some 
authors argue that large, global matrix structures in reality often become a contradiction of the ideal flexible model. They become heavy bureaucracies with doubled headcount and doubled, contradictory processes, unable to respond quickly to the rapidly changing multinational environment (Guterl, 1989). This happens when the top management is hesitant to manage in a more democratic way and distribute the authority to the lower levels of the organization, which becomes "top heavy". That being said, it is important to underline that the empirical evidence for all these points has usually a qualitative character.

\section{Balance of power}

Given the multiple authority in a matrix structure, it is a desired goal to reach a balance of power among its dimensions, such as project, functional or geographic ones (Hopej-Kamińska, Hopej and Kamiński, 2013; Stuckenbruck, 1982). In fact, this is the only way to minimize potential power struggles and conflicts. Importantly, a balance of power does not mean it is equal among various dimensions of the organization (Katz and Allen, 1985). On the contrary, to reach this state, the distribution of power needs to be flexibly adjusted to the specific organizational context (Stuckenbruck, 1982). That being said, in a matrix, this task is much more challenging than the typical issue around centralization or decentralization of resources, known from traditional hierarchies (Anderson, 1994). Some of the possible dimensions along which a matrix might be required to be balanced are presented in Figure 2.
Only a few authors indicate that the instability of authority in a matrix might be beneficial. Kingdon sees the matrix as a way to find a balance among the needs of customers (project completion), functional departments (technical excellence and development of technical capability for the future) and business or project units (profit). He presents customers and project teams as pulling towards own opportunism and functional teams towards utopianism - with the matrix holding the fragile balance between them (Kingdon, 1973; Brown and Agnew, 1982). On the other hand, from the perspective of general managers, the increased flexibility in manipulating the balance of power within a matrix organization might be considered as an additional source of power for themselves (Lawrence, Kolodny and Davis, 1977). That being said, such voices proved to be a minority among analyzed publications.

A significant majority of authors, given the multiplied authority in matrix organizations, perceive balancing the power in them as a big challenge (Galbraith, 2008; Gottlieb, 2007; Lawrence et al., 1977; North and Coors, 2010). The need to balance conflicting objectives is deeply rooted in the multidimensionality of this structure type. Kingdon underlines the difficulty in finding the right balance of power between project and functional managers, who compete for the organizational influence (Kingdon, 1973; Knight, 1976; Schermerhorn, 2008). The level of the project manager's power and its impact on his ability to deliver the project is a frequently discussed issue. It often happens that project managers feel responsible for projects and have to con-

Figure 2. Sample trade-off fields in balancing a matrix structure

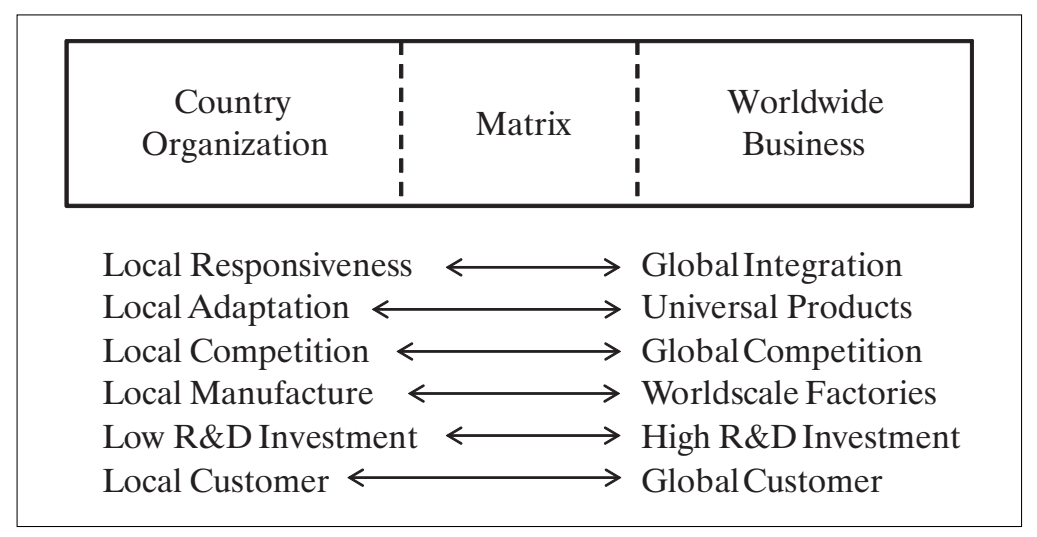

Source: Galbraith and Kazanjian (1986). 
vince the functional management to support their initiatives, which is an obvious distraction (Wilemon and Gemmill, 1971). Additionally, at a more operational level, two kinds of influence: horizontal and vertical are often negatively correlated. The more successful the first type of communication is, the more difficult the vertical (hierarchic) cooperation becomes, as the more senior managers feel omitted in the discussions. Also conversely, the better the hierarchic cooperation works, the higher are the chances of lateral conflicts. Not all employees are willing to cooperate with the "boss's pet" and business activities suffer from disputes and poor communication (Kingdon, 1973).

As in the case of other characteristics, hard evidence is limited in the discussion about the balance of power in matrix structures. That being said, Katz and Allen identified quantitatively a positive correlation between project performance and the level of perceived balance between project and functional managers over salaries and promotions (Katz and Allen, 1985).

\section{Level of conflicts}

Most writers agree with Simon, who stated that "life within the matrix remains stressful and full of conflict" (Simon, 1983, p. 359). They point to the level of conflicts associated with implementing a matrix structure as a major disadvantage of this concept (Davis and Lawrence, 1978; Derven, 2010; Joyce, 1986; Kisielnicki, 2014; Knight, 1977; Kolodny, 1979; Numerof and Abrams, 2002; Prahalad, 1976; Simon, 1983; Strikwerda and Shoelhorst, 2009; Whitford, 2006; Wilemon, 1973; Zdziarski, 2014). As mentioned previously, the boundaries of authority and responsibility of functional and project managers in a matrix organization are often unclear or overlapping. The resulting ambiguity surrounds the allocation of resources, technical issues, salaries, personnel assignments, promotions and project responsibilities (Ludwig, 1970; Atkinson, 2003; Galbraith, 1971; Greiner and Schein, 1981; Katz and Allen, 1985; Kesler and Schuster, 2009; Larson and Gobeli, 1987; Lawrence et al., 1977; Prahalad, 1976). This ambiguity often results in a state of permanent organizational conflict, as each side struggles to clarify its scope of responsibility and resources. Such a conflict negatively affects the organization in several ways, namely at the following levels: (1) Organizational, (2) Departmental, (3) Individual (Argyris, 1967; Davis and Lawrence, 1977; Denis, 1986a; Derven, 2010; Larson and Gobeli, 1987; Numerof and Abrams, 2002; Posner, 1986).

The first level mentioned relates mostly to multinational corporations. In large global matrix organizations, a frequent source of conflicts is the division into global and local divisions with an unclear responsibility split (Kesler and Schuster, 2009; Prahalad, 1976). Leaders of geographic divisions are focused on responding flexibly to the changing local environment, whereas global product leaders aim more at standardization and economy of scale at the global level (Duliniec, 2009).

The second level refers mainly to conflicts between functional and project departments. Some authors argue that introducing a matrix structure might intensify defensive and hostile attitudes among managers, which in fact is contrary to what matrix was designed for in the first instance (Argyris, 1967; Derven, 2010; Gottlieb, 2007). The most common type of conflicts are those between functional and project managers and their departments (Barker, Tjosvold and Andrews, 1988). As the matrix structure breaks down the departmental barriers which exist in a traditional hierarchy, departments in a matrix compete over responsibility, decisiveness, influence, resources, procedures, technical excellence and personalities. This is a quite intuitive result of the doubled lines of reporting in a matrix. The intensity of this conflict may also vary over the course of the project (Barker et al., 1988).

The third point refers to conflicts at the individual level (Meredith and Mantel, 1989; Smith, 1978; Stuckenbruck, 1982). This type of conflicts in a matrix is usually associated with intensified interaction among people from very different departmental backgrounds, who do not have such exposure to one another in a traditional hierarchical structure. It can mean, for instance, a clash between project and process orientation, long-term and short-term perspective, opposite personalities or simply different values (Dill and Pearson, 1984; Joyce, 1986; Katz and Allen, 1985; Posner, 1986). Also, because of reporting to two or more, often very different bosses, indi- 
viduals find themselves working simultaneously on various projects under different managers. This situation results in "multiple reporting relationships (role conflict), conflicting and confusing expectations (role ambiguity) and excessive demands (role overload)" (Ford and Randolph, 1992, p. 276; Joyce, 1986). Functional managers often consider a matrix organization as a deterioration of their status and authority, as they need to share the control over their traditional domain (Wall, 1984). This often contributes to their hostile approach to the implementation of a matrix structure (Davis and Lawrence, 1978). Lorsch and Lawrence indicate that the negative approach of functional staff to the matrix is caused partly by erosion of their autonomy, but more from the perspective of implementation of more democratic group decision-making. Technical experts often feel forced to violate their procedures, rules and norms, with a negative impact on technical excellence (Lorsch and Lawrence, 1972). One interesting aspect of individual conflicts is raised by Whitford, who points out that they often cannot be resolved at the lower levels, which leads to frequent escalations and resulting role overload for the managers (Whitford, 2006).

Many authors tried to explain how exactly a matrix structure causes conflicts, indicating various reasons (Barker et al., 1988; Denis, 1986a; Katz and Allen, 1985; Kerzner, 1984; Wilemon, 1973; Wilemon and Thamhain, 1983). They seem to be well covered by a proposal by Wilemon, a list of eight conditions, negatively or positively correlated with the potential for conflict in a matrix structure (Wilemon, 1973):

- diversity of disciplinary expertise (positive correlation)

- power of project manager (negative correlation)

- concreteness and understanding of project objectives by the project team (negative correlation)

- role ambiguity of project team members (positive correlation)

- agreement on "superordinate" goals by project team participants (negative correlation)

- perception by functional staff that the matrix will adversely usurp their roles (positive correlation)

- perceived need for interdependence among units (negative correlation)
- managerial level in the organization (positive correlation - more conflicts at higher levels)

Although, as mentioned before, authors mostly agree that conflicts are a primary disadvantage of matrix structures, there are some interesting, voices to the contrary in this discussion. Gottlieb argues that through proper management of conflicts among managers and departments, managers of matrix organizations might efficiently balance the power in the organization. This can convert the conflict into a fruitful discussion, leading to more optimal decisions (Gottlieb, 2007). A similar approach is presented by Knight, who indicates two types of conflict in a matrix, purposeful and dysfunctional (Knight, 1977). Research by Barker et al. also proved that a conflict in a matrix might have positive or negative effects, depending on the way the organization is managed. In cases where managers were using a mix of co-operative and confirming approaches to conflict, conflicts were considered to have a constructive impact. They were seen as counterproductive when managers used a mix of competitive and avoiding approaches to conflict (Barker et al., 1988). Stuckenbruck mentions that matrix management, although struggling with many types of conflict, is a solution to the "basic conflict inherent in any organization - the needs of specialization versus the needs of coordination" (Stuckenbruck, 1982, p. 211). Likert suggests an interesting "chicken and egg" discussion about conflicts and communication in matrix structures, wondering whether poor communication in a matrix leads to intensified conflicts or the direction of this dependency is in fact the opposite (Likert, 1976).

The evidence on conflicts in matrix organizations is usually rather qualitative. Joyce in his case study came to a conclusion that higher levels of role ambiguity were indeed linked with the implementation of a matrix structure. That being said, he found no evidence for role conflict in the investigated matrix case (Joyce, 1986). An important piece of evidence comes from Whitford, who indicates that the implementation of a matrix increases the level of conflicts by 75\% (Whitford, 2006). Contrary evidence was provided by Wolf and Egelhof (Wolf and Egelhof, 2013). They investigated 82 multinational matrix 
organizations and concluded that only one type of matrix structures caused increased levels of internal conflict. According to the research, only multinationals with a "[...] product division by geographical region matrix structure support the hypothesis. Other types of matrix structure which contain a functional division dimension tend to have levels of intra-organizational conflict similar to elementary structures" (Wolf and Egelhof, 2013).

\section{Conclusion}

One apparent conclusion can be drawn from the conducted review: there is still a lot to learn about the circumstances and practices that relate to the key characteristics of matrix organizations. The analysis covered a substantial part of the available literature on matrix organizations since the beginning of the discipline, ending with the most recent sources. Judging only by the number of publications on matrix organizations, it would appear that it is a quite well explored field. In reality, the empirical evidence proved to be very limited and a large portion of higher quality sources dates back to the 1970s and 1980s, although matrix structures are present in many modern corporations.

Eight key characteristics were identified in the literature and verified to understand whether they are perceived as advantages or disadvantages of matrix structures. The analysis revealed that three of the characteristics (managing complexity, communication effectiveness, output quality) are usually perceived as advantages of matrix organizations, one (level of conflicts) was predominantly presented as a disadvantage and four (cost effectiveness, motivation and job satisfaction, decision-making effectiveness, balance of power) arouse controversies among authors as to whether they are positives or negatives. It is safe to assume that matrix structures have a lot of positive influences, but they also inevitably come with a number of disadvantages. The characteristics which seem the most interesting are naturally the controversial ones, which can be labeled as "matrix paradoxes". Further research could, on the one hand, focus on clarifying whether these characteristics are beneficial or not. On the other, it could identify factors which make them become a benefit or a flaw. Identifying these factors would be a significant step ahead in understanding the functioning of modern matrix organizations.

\section{References}

Anderson, R. E. (1994). Matrix Redux - Matrix Management. Business Horizons, 37(6), 6-11.

Appelbaum, S. H., Nadeau, D. and Cyr, M. (2008). Performance evaluation in a matrix organization: a case study (Part One). Industrial and commercial training, 40(5), 236-241.

Argyris, C. (1967). Today's Problems with Tomorrow's Organizations. Journal of Management Studies, 4(1), 31-55.

Atkinson, P. (2003). Managing Chaos in a Matrix World. Management Services, 47(11), 8-11.

Barker, J., Tjosvold, D. and Andrews, R. I. (1988). Conflict approaches of effective and ineffective project managers: A field study in a matrix organization. Journal of Management Studies, 25(2), 167-178.

Bartlett, C. A. and Ghosal, S. (1990). Matrix Management: Not a Structure, a Frame of Mind. Harvard Business Review, July-August, 2-8.

Bresnen, M. (1990). Organising Construction. Project Organisation and Matrix Management. New York: Routledge.

Brown, J. L. and Agnew, N. (1982). The Balance of Power in a Matrix Structure. Business Horizons, 25(6), 51-55.

Butler, N. M. (1973). Project management: A study of organizational conflict. Academy of Management Journal, 16, 84-102.

Cleland, D. I. (1981a). The cultural ambience of the matrix organization. Management Review, 70(11), 24-31.

Cleland, D. I. (1981b). Matrix management (Part II): A kaleidoscope of organizational systems. Management Review, 70, 48-56.

Cummings, J. N. (2004). Work Groups, Structural Diversity, and Knowledge Sharing in a Global Organization. Management Science, 50(3), 352-364.

Daft, R. L. (2007). Organization Theory and Design. Mason: Thomson/Southwestern.

Davis, K. (1967). Human Relations at Work (3rd $E d$.). New York: McGraw-Hill.

Davis, S. M. and Lawrence, P. R. (1977). Matrix. Reading: Addison-Wesley.

Davis, S. M. and Lawrence, P. R. (1978). Problems of matrix organizations. Harvard Business Review, 56(3), 131-142.

Denis, H. (1986a). Is the matrix organization a cumbersome structure for engineering projects? Project Management Journal, 17(1), 49-55. 
Denis, H. (1986b). Matrix structures, quality of working life, and engineering productivity. IEEE Transactions on Engineering Management, 33(3), 148-156.

Derven, M. (2010). Managing the Matrix in the New Normal. Training and Development Magazine, 64(7), 42-47.

Dill, D. and Pearson, A. W. (1984). The effectiveness of project managers: Implications of a political model of influence. IEEE Transactions on Engineering Management, 31(3), 138-146.

DiMarco, N., Goodson, J. R. and Houser, H. F. (1989). Situational leadership in a project/matrix environment. Project Management Journal, 20(1), 11-18.

Duliniec, E. (2009). Marketing międzynarodowy. Warsaw: PWE.

Egelhoff, W. G., Wolf, J. and Adzic, M. (2013). Designing Matrix Structures to Fit MNC Strategy. Global Strategy Journal, 3, 205-226.

Ford, R. C. and Randolph, W. A. (1992). CrossFunctional Structures: A Review and Integration of Matrix Organization and Project Management. Journal of Management, 18(2), 267-294.

Galbraith, J. R. (1971). Matrix Organization Designs. How to combine functional and project forms. Business Horizons, 14(1), 29-40.

Galbraith, J. R. (1973). Designing Complex Organizations. Reading: Addison-Wesley.

Galbraith, J. R. (1977). Organization design. Reading: Addison-Wesley.

Galbraith, J. R. (2008). Designing Matrix Organizations That Actually Work: How IBM, Procter \& Gamble and Others Design for Success. San Francisco: Jossey-Bass.

Galbraith, J. R. (2013). Matrix Management: Structure is the Easy Part. People and Strategy, 36(1), 6-7.

Galbraith, J. R. (2014). Designing Organizations: Strategy, Structure, and Process at the Business Unit and Enterprise Levels (3rd Ed.). New York: John Wiley \& Sons.

Gobeli, D. and Larson, E. W. (1987). Relative effectiveness of different project structures. Project Management Journal, 18(2), 81-85.

Goggin, W. C. (1974). How the Multi-dimensional Structure Works at Dow-Corning. Harvard Business Review, 52(1), 54-65.

Gottlieb, M. R. (2007). The Matrix Organization Reloaded: Adventures in Team and Project Management. London: Praeger Publishers.

Greiner, L. E. (1972). Evolution and Revolution as Organizations Grow. Harvard Business Review, 50(4), 43-44.

Greiner, L. E. and Schein, V. E. (1981). The paradox of managing a project-oriented matrix: Estab- lishing coherence within chaos. Sloan Management Review, 2(2), 17-22.

Guterl, F. V. (1989). Goodbye old matrix. Dun's Business Month, 133, 32-38.

Herzberg, F., Mausner, B. and Snyderman, B. B. (1959) The motivation to work (2nd Ed.). New York: John Wiley \& Sons.

Hill, R. (1974). Corning Glass Reshapes its International Operations. International Management, 29(10).

Hopej-Kamińska, M., Hopej, M. and Kamiński, R. (2013). Epoki strukturalne. Research papers of Wroctaw University of Economics, 277, 113-119.

Hrebiniak, L. G. and Joyce, W. F. (1984). Implementing strategy. New York: Macmillan Book Publishing.

Hutt, M. D. (1995). Cross-Functional Working Relationships in Marketing. Journal of the Academy of Marketing Science, 23(4), 351-357.

Jerkovsky, W. (1983). Functional management in matrix organizations. IEEE Transactions on Engineering Management, 30(2), 89-97.

Joyce, W. F. (1986). Matrix organization: A social experiment. Academy of Management Journal, 29(3), 536-561.

Katz, R. and Allen, T. J. (1985). Project performance and the locus of influence in the R \& D matrix. Academy of Management Journal, 28(1), 67-87.

Kerzner, H. (1984). Project management. A systems approach to planning, scheduling and controlling. New York: Van Nostrand Reinhold.

Kesler, G. and Schuster, M. H. (2009). Design Your Governance Model to Make the Matrix Work. People \& Strategy, 32(4), 16-25.

Kingdon, D. R. (1973). Matrix Organization. London: Tavistock.

Kisielnicki, J. (2014). Zarządzanie. Jak zarządzać i być zarzadzanym. Warsaw: PWE.

Knight, K. (1976). Matrix Organization: A Review. The Journal of Management Studies, 13(2), 111-130.

Knight, K. (1977). Matrix Management: A Crossfunctional Approach to Organisation. Westmead: Gower Press.

Kolodny, H. F. (1979). Evolution to a matrix organization. Academy of Management Review, 4(4), 543-553.

Kolodny, H. F. (1980). Matrix organization designs and new product success. Research Management, 23(5), 529-533.

Kolodny, H. F. (1981). Managing in a matrix. Business Horizons, 24(2), 17-24.

Kur, C. E. (1982). Making matrix management work. Supervisory Management, 27(3), 37-43. 
Larson, E. W. and Gobeli, D. H. (1987). Matrix management: contradictions and insights. California Management Review, 29(4), 126-138.

Lawrence, P. R., Kolodny, H. F. and Davis, S. M. (1977). The Human Side of Matrix. Organizational Dynamics, Summer, 43-61.

Lawrence, P. R. and Lorsch, J. W. (1967). New Management Job: The Integrator. Harvard Business Review, November-December, 142-151.

Lawson, J. W. (1986). A quick look at matrix organization from the perspective of the practicing manager. Engineering Management International, 4 , 61-70.

Likert, R. (1976). Improving cost performance with cross-functional teams. Management Review, 65(3), 36-43.

Lorsch, J. W. and Lawrence, P. R. (1972). Organization Planning: Cases and Concepts. Homewood: Irwin-Dorsey.

Ludwig, S. (1970). The Move to Matrix Management. Management Review, 59(6), 60-65.

Marquis, D. (1969). Ways of Organizing Projects. Innovation, 5, 26-33.

Mee, J. F. (1964). Matrix Organization. Business Horizons, 7(2), 70-72.

Meredith, J. R. and Mantel, S. J. Jr (1989). Project Management (2nd Ed.). New York: John Wiley.

Naylor, T. H. (1985). The International Strategy Matrix. Columbia Journal of World Business, 20(2), 11-19.

Nesheim, T. (2011). Managing Process Ownership and Line Management in a Matrix-like Organization. Knowledge and Process Management, 18(2), 109-119.

North, M. and Coors, C. (2010). Avoiding death by dotted line. Healthcare financial management, 64(1), 120-121.

Numerof, R. E. and Abrams, M. N. (2002). Matrix management: Recipe for chaos? Organization Management, 26(4), 42-45.

Parker, G. M. (1994). Cross-Functional Teams: Working with Allies, Enemies, and other Strangers. San Francisco: Jossey-Bass.

Perham, H. (1970). Matrix Management: a Tough Game to Play. Dun's Review, August, 31-34.

Pitts, R. A. and Daniels, J. D. (1984). Aftermath of the matrix mania. Columbia Journal of World Business, 19(2), 48-54.

Posner, B. Z. (1986). What's all the fighting about? Conflicts in project management. IEEE Transactions on Engineering Management, 33(4), 207-211.

Prahalad, C. K. (1976). Strategic choices in diversified MNCs. Harvard Business Review, 54(4), 67-78.
Randolph, W. A. and Posner, B. Z. (1992). Getting the job done: Managing project teams and task forces for success. Englewood Cliffs: Prentice-Hall.

Raza, S. and Standing, C. (2011). A Systemic Model for Managing and Evaluating Conflicts in Organizational Change. Systemic Practice \& Action Research, 24(3), 187-210.

Reeser, C. (1969). Some potential human problems of the project organization. Academy of Management Journal, 12, 459-467.

Rizzo, J. R., House, R. J. and Lirtzman, S. I. (1970). Role conflict and ambiguity in complex organizations. Administrative Science Quarterly, 15, 150-163.

Russell, E. (1999). Time is of the essence. Automotive Engineer, 24(5), 31-32.

Schermerhorn, J. R. (2008). Zarzadzanie. Warsaw: PWE.

Simon, M. E. (1983). Matrix Management at the U.S. Consumer Product Safety Commission. Public Administration Review, 43, 357-361.

Smith, H. R. (1978). A socio-biological look at matrix. Academy of Management Review, 3(4), 922-926.

Strikwerda, J. and Stoelhorst J. W. (2009). The Emergence and Evolution of the Multidimensional Organization. California Management Review, 51(4), 11-31.

Stuckenbruck, L. C. (1982). The implementation of project management: The professional's handbook. Reading: Addison-Wesley.

Sy, T. and D'Annunzio, L. S. (2005). Challenges and Strategies of Matrix Organizations: Top-level and Mid-level Managers' Perspectives. Human Resource Planning, 28(1), 39-48.

Taylor, A. (1999). Compaq Looks Inside for Salvation. Fortune, August 16, 126.

Turner, S. G., Utley, D. R. and Westbrook, J. D. (1998). Project Managers and Functional Managers: A Case Study of Job Satisfaction in a Matrix Organization. Project Management Journal, 29(3), 11-19.

Wall, W. C. Jr (1984). Integrated management in matrix organization. IEEE Transactions on Engineering Management, 31(1), 30-36.

White, K. B. (1979). Alternative forms of project organization. In: R. Hill and B.J. White (eds.), Matrix organization and Project Management. Ann Arbor: MI Business Papers.

Whitford, A. B. (2006). Unitary, Divisional and Matrix Forms as Political Governance Systems. Journal of Management Governance, 10, 435-454.

Wilemon, D. L. (1973). Managing Conflict in Temporary Management Systems. Journal of Management Studies, 10(3), 282-296. 
Wilemon, D. L. and Gemmill G. R. (1971). Interpersonal Power in Temporary Management Systems. Journal of Management Studies, 8(3), 315-328.

Wilemon, D. L. and Thamhain, H. J. (1983). Team building in project management. Project Management Quarterly, 14(3), 73-81.

Wolf, J. and Egelhof, W. G. (2013). An empirical evaluation of conflict in MNC matrix structure firms. International Business Review, 22(3), 591-601.
Wright, N. H. (1980). Matrix management - fortifying the organization structure. Manufacturing World, May, 24-26.

Youker, R. (1977). Organization alternatives for project managers. Management Review, 66(11), 46-53. Zdziarski, M. (2014). Struktury firm międzynarodowych. In: K. Obłój and A. Wąsowska (eds.), Zarzadzanie międzynarodowe. Teoria $i$ praktyka (pp. 127-157). Warsaw: PWE. 